\title{
The schooling experiences of Pasifika students
}

\author{
ANNIE SIOPE
}

\section{KEY POINTS}

- Education is an important aspiration for Pasifika families, but for many, the "migrant dream" is not reflected in the reality of Pasifika students' experience of secondary schooling, neither a generation ago nor for the current generation of students.

- Pasifika students live in "siloed" worlds in which their school, family and church lives are kept separate, and students learn not to draw attention to themselves at school.

- The church plays an important cultural and community role for Pasifika families, but requires a significant commitment of time from Pasifika students.

- Teachers who are responsive, readily accessible and reasonable are the key to unlocking educational success for Pasifika students. Such teachers, secure in their own cultural identity and who encourage the same from their students, unlock the educational potential in Pasifika students, enabling them realise the "migrant dream". 
The growing diversity of students in mainstream schools in Aotearoa New Zealand is challenging for educators and policy makers alike. Educational researchers in the 21 st century have shown that listening to what students have to say about what works best for them is more important than ever. This article discusses the narratives of schooling experiences of two generations of Pasifika students, comparing the experiences of Pasifika students from Auckland secondary schools involved in the Te Kotahitanga project in 2009 with the author's schooling experiences in the mid-1970s to the early 1980s.

Since the end of World War Two, Pacific Islands peoples have migrated to Aotearoa New Zealand in the hopes of a better life and increased prosperity, with education the key to making these dreams a reality. In Aotearoa New Zealand, the Ministry of Education uses the term Pasifika to describe people living in Aotearoa New Zealand who have migrated from Pacific Island nations or who identify with Pacific Island nations because of ancestry or heritage. However, like the term Mãori, Pasifika does not denote a single homogeneous ethnicity, nationality or culture. Statistics New Zealand (2007) collects data on Pacific peoples in Aotearoa New Zealand that relate specifically to the seven largest Pacific ethnic groups residing here. From largest to smallest in population size, these groups are: Samoan, Cook Islands Māori, Tongan, Niuean, Fijian, Tokelauan and Tuvaluan. In the 2006 census, Pacific peoples equated to 6.9 percent $(265,974)$ of the New Zealand demographic, a noticeable rise from 5.1 percent of the 1991 census. The majority of Pacific peoples live in the Auckland region (67 percent), followed by the Wellington region (13 percent) and 7 percent in the South Island. The median age of Pacific peoples in 2006 was 21.1 years, which is considerably lower than the median age of the New Zealand population overall (35.9 years).

In terms of education, the majority of Pasifika students attend mainstream schools in Aotearoa New Zealand. Within their families there is an assumption that all schools are good and all offer the same quality of education (Ferguson, Gorinski, \& Wendt Samu, 2008).

This article is derived from my master's thesis (Siope, 2010): Children of the Migrant Dreamers: Comparing the Experiences of Pasifika Students in Two Secondary Schools Attempting to be Culturally Responsive to Mine a Generation Ago. This thesis was undertaken with ethical approval from the University of Waikato. The term migrant dreamers comes from two poems written by Karlo Mila (2005), now Mila-Schaaf, of Tongan-Samoan-Palagi ${ }^{1}$ heritage, from her book of poems Dream Fish Floating. The migrant dreamers Mila-Schaaf refers to are the Pasifika migrants who have come to Aotearoa New Zealand in the hopes of a better life for themselves, with education the ticket to achieving their "milk and honey" dreams. However, for these migrant dreamers' children, the so-called fat of the Promised Land has soured, with Pasifika and Māori children sharing the same negative statistics of obesity, diabetes, heart disease, academic underachievement and poverty.

I purposely chose to focus on the schooling experiences of students from two secondary schools, in terms of how culturally responsive these schooling experiences had been. Culturally responsive in this instance means schools that are proactively moving beyond superficial culturally appropriate tokenistic efforts to seeking to better understand and meet their students' needs, using student evidence and research to inform their practice. I wanted to know firsthand what the experiences of Pasifika students in these schools had been in comparison to my own. In sharing these schooling experiences in this article, I will focus on five main themes. Each time I will begin with my own experiences and then draw upon the experiences of this group of 21st century Pasifika students. I will conclude with the challenges that continue to be faced by generations of Pasifika students and some of the implications for their educators. 


\section{Children of the migrant dreamers:}

\section{Aspirations of education}

I am the third of four children born to Samoan migrant parents. Our schooling experiences took place in the shadow of the dawn raids in the 1970 s, when being a Pacific Islander was both unpopular and unsafe. Anae (2009), in her research, found that from 1964 to 1967 , the government's immigration policy had issued 3-month visas and set annual quotas for immigrants. However, these regulations were not enforced as the demand for unskilled labour was strong. But when Britain, New Zealand's biggest export market, became a member of the European Economic Community in 1973, the economy declined and this flexibility in immigration policy ended. Dawn raids on the homes of alleged overstayers began in 1974 when politicians blamed Pacific Islanders for overloading social services and taking jobs from $\mathrm{New}$ Zealand residents, and negative stereotypes of Pacific Islanders were reinforced.

My siblings and I quickly learnt the art of being invisible at school, where we would balance navigating our educational outcomes between the micro- and macrorealities of our lives. The micro-reality included keeping our aiga (family members, both immediate and extended) happy, yet not being so visible or noticeable as to bring negative attention from school peers and, dare I say it, teachers in general. In actuality, what we had done was merely to train up our minds for learned helplessness. However, we always knew that education was important to our families, especially knowing the stories of my grandfather, a man with the most beautiful penmanship, who worked at Hellaby's meat works. My mother often reminded us that grandpa's sacrifice was working the factory floor so that his children and his children's children would not have to.

Likewise, the students of this 21st century generation shared similar idealistic stories of why their families had migrated to New Zealand, and how their deepest desire was to make their families proud as a means of rendering service, outwardly showing their love and respect for them and, conversely, not shaming them either.

Y12 Lalo (Samoan): Education is like a dream for my parents. Back in the Islands, school is not as good as what we have here, so education right now is everything because if you have qualifications you can get anywhere, money and stuff, because that's basically it, it's money 'cause without it you can't survive. And another thing, our parents don't want us to work in factories and stuff, like hard labour for less pay, qualifications that can get you somewhere.

Y12 Sione (Samoan): My family, they're not rich and they're not poor too but I want to be wealthy and that's why I'm trying my best to get a good future and help out my parents. It's about giving back to your parents especially because my dad, like, both of my parents, giving back what they gave us and for all their hard work, because if it wasn't for them I wouldn't get a good future.

Y11 Lillian (Tongan): Basically making my parents proud, giving them what my older brothers and sisters didn't give them, setting up a brighter future, make it easy for me in the future, living life happy. Getting scholarships is big as to my parents. A university scholarship would be major. I'd like to do travel and tourism.

Lillian comes from a large family where her older brothers and sisters had gone ahead of her. Unfortunately, none of her siblings had gone on to further education. She shared how her unwed sisters had returned home with their own infant children. And how her brothers, who had moved overseas to Australia, never sent any money back home to help the rest of the family. She also shared the added pressure not only of her parents' hopes being shifted on to her shoulders, but also pressure from her older siblings. All wanted her not only to succeed on their behalf but also to set a good example to their younger siblings and to her nephews and nieces.

\section{Siloed experiences: Home and school}

Hawk and Hill (1998) discuss how Pasifika students, especially in their secondary schooling years, can live in up to six or seven different worlds. These include the worlds of home, school, church, sports, other extracurricular activities, part-time employment and friends. What Hawk and Hill found most surprising was the way in which these students tried to keep their worlds as separate from each other as possible. Furthermore, they wanted to keep this knowledge separate from their parents and caregivers. With regard to assessing our academic outcomes, apart from the twice yearly summative school reports, which would either end in tears or a pat on the head, my parents knew little of what or how we did in school. For my siblings and me, unfortunately, we became our own gatekeepers of learning and, in many ways, sabotaged our futures by not allowing our parents to be a part of our siloed worlds. This was relatively easy to do given that we were all involved in parttime employment during our secondary schooling years and both parents were working full-time jobs.

In this regard, I found similarities between the current generation of students and my own schooling experience. Junior told how he lived at home with his older brother and his brother's girlfriend, 10 years his senior. He told me his parents were back in Tonga and had sent their sons here to get an education. Like Lillian's older siblings, Junior's brother left school early.

Y9 Junior (Tongan): I look after my nieces and they can be real loud! I like to sleep a lot so I try to take them some place 
where it's quiet where they can't really talk. I take them to the [local] library and every Friday there's [external youth programme], a place where there's volleyball and rugby and they love it there. I make sure they stay under control and not get too cheeky. But they get cheeky anyway. I look after them every day. They go to sleep about $8 \mathrm{pm}$. My brother cooks for them but if he goes to work then I cook for them. Junior told how his homework was done late at night, usually at 10 or 11 o'clock, when he would often try to "skive off" from doing it. However, when his brother returned from work, he would always check that it had been done. Junior cited his brother as being his main motivator, stating that he'd often tell him not to end up as he had, working changeable shift hours and living from pay check to pay check. Like Faith in another school, Junior relayed how his brother had warned him to "stay under the radar", which would keep him out of trouble.

I understood exactly what Junior's brother was referring to; the brother believed that if Junior became visible, he risked being put down a level into a class associated with the naughty kids - where no one learnt anything because the class's priorities were behavioural management, discipline and crowd control rather than learning. Like my own schooling experiences, secondary school had taught Junior to keep his family and home tasks separate from his school tasks.

\section{A responsive, readily available and reasonable adult}

Most people can remember certain adults who have motivated or inspired them-not necessarily a teacher or family member, but someone who was in some way able to activate the appropriate connections in their educational pathways that would utilise or ignite their learning potential. Such individuals have affected their lives either for good or ill, and they are not necessarily the ones associated with being positive role models. Stanley (2003) posits that, in order for students to succeed in school, they "need to be connected and they need to feel that they belong, and this requires reasonably ready access to a responsive and reasonable adult" (p. 26). This "responsive", "reasonable", "readily accessible" adult should, of course, be the classroom teacher, for, as many researchers have deduced, it is the teacher who has the biggest influence on student achievement (Bishop \& Glynn, 1999; Hattie, 2003; Nuthall, 2007).

My responsive, readily available, reasonable adult was the teacher in charge of lunchtime detention, a Palagi maths teacher whom I will call Mr Johnson (a pseudonym). This man metaphorically saved my life and, fortunately, rescued me and my wagging companions from academic suicide and short-sightedness.
Mr Johnson's lunchtime detentions were different. He told us that during our time together, we weren't to pick up litter. This was to be done in our own time. Furthermore, we were told we weren't there to write "insincere, tokenistic apology letters" to the teachers whose classes we had wagged. If there were apologies to be made, then we were to "man up" and go in person to apologise. And if that wasn't humiliating or humbling enough, as well as the face-to-face apologies, we were to further ask those teachers what it would take for us to appease them, to make it right. This behavioural expectation was not unfamiliar to us as we were versed in the ways of ifoga (Tuala-Warren, 2004), which are the Samoan disciplinary restorative practices of the fa'amatai system of village governance. Mr Johnson's disciplinary methods resembled these practices of restoring calm, righting wrongs and re-establishing filemu (peace, absence of contention).

His maths lessons were different, compared with our usual maths classes. There were no worksheets, no talking over our heads like some of our other teachers, who used fancy jargon to make them sound "flash". When we asked for explanations, they resorted to condescending put-downs and impatience. In Mr Johnson's class, we felt like adults, his equals, not so much in terms of expertise but in the way he spoke to us, never raising his voice. He never blamed us for what we knew or did not know. Other teachers would tell us, "You're in the fifth form now, you should already know this." It was his job, he told us, to show us how really smart we were. I would not go as far as to say that he was our "mate", but he was someone who, over time, we grew to respect. We knew that he cared for us and that he was true to his word.

According to Year 11 Samoan student, John, at his school there were no ineffective teachers. However, when he voiced this opinion, the girls in the group were quick to point out that the teachers tended to favour the boys over the girls, and the conversation tone changed from ineffective teachers being racists to ineffective teachers taking favourites. In this case it meant boys.

\section{Just the way they show it, it's all messed up!}

Although not included in my interview questions, the subjects of racism and its sidekick, bullying, were brought up in all student groups when describing ineffective teachers. Research conducted by Rubie-Davies, Hattie and Hamilton (2006) found teacher expectations to be the biggest barrier to improving student outcomes and that teacher expectations were often based on the ethnic stereotypes that teachers had of their students. But their most surprising finding was that teachers were largely 
unaware of their beliefs, their perspectives about ethnicities and the cultural differences in their classrooms.

Likewise, the students in this study also shared that those teachers whom they deemed ineffective were the ones who were clueless about the real happenings within the classroom and about what was happening in their lives outside of school. The teachers were described as selfish, uninterested in others, miserable with life and the ones who just wanted to teach their subject, not the students. Nita summed it up well:

Y12 Nita (Niuean): Some teachers won't let students talk about their personal problems and see it as stupid, and we get the feeling that they're racist or something. But they're not, [it's] just the way they show it. It's all messed up!

It is as Gay (2000) posits, "[w]hilst most teachers are not blatant racists, many probably are cultural hegemonists. They expect all students to behave according to the school's cultural standards of normality" (p. 46). What Nita is referring to as being "messed up" is the cultural hegemonic practices of a monocultural society, for, although these may be unseen, they become fully operational within classrooms when teachers believe discourses such as "no smiling until April", "term 1 is about showing them you're the boss", "this unit must be taught by ...". When students did choose to exercise their agency and tried standing up for their rights to an education, they were dealt to severely:

Y9 Lisa (Samoan): And I got angry this one time because he wouldn't help me so I told him straight up! And I go, I'm sick of you not helping me and here I am trying to learn, just for my education and that, and trying to do my goals and that, and all he said was, 'Do it yourself' and gave me a warning for no reason, just for telling him straight up. And then he got angry and sent me outside.

In order to achieve, by their third year in secondary school many Pasifika students had learnt the covert rules of engagement on how to behave, conceding to the pervasive culture of dominance. Glynn and Berryman (2005) describe the same scenario for Māori students having to leave their home cultures at the school gates in order to achieve academically.

Faith speaks of how she and the other 30 percent of non-Palagi students in her form class purposely distanced themselves from the brainy white people because of the assumptions she believes that they have of her. Her comments illustrate the power of stereotypes in upholding hegemonic practices:

Y11 Faith (Samoan): Yeah my form class is, like, 70 percent all white people. I don't really hang out with them ... We're, like, under the radar, kind of. We don't really talk! Because people say Islanders aren't like brainy [like] Palagis are, but if you get in a higher class like them, then you'll see, I'm brainy. Islanders are brainy!
The next example shows a student's perception of some teachers' misguided treatment of Māori students in their school. However, Sina is unaware of behaving the same way herself with her own incorrect use of Māori. The school culture is evidenced in the fact that no one had ever made the attempt to correct her:

Y12 Sina (Cook Islands Māori): And other teachers believe that some Māoris [sic] will probably slap them and think that all of them are like that because that's how they've been brought up to think, that Māoris $[s i c]$ are like this and PIs are like this, and then they bring it into school and treat all the students that are that race the same way, when not everyone is.

When the question came up, the students still remained tentative about sharing schooling experiences with parents and other family members, even with parents who themselves were schooled in Aotearoa New Zealand:

Y13 Dave (Samoan): I don't usually like talking about school with my family, just my mum, she's NZ-born, but not really. Yeah, when my dad asks, but I'm just like, 'Yeah I'm doing good!' But if I get to my report before my mum does then I don't give it to her [laughter].

Y12 Cynthia (Tongan): I once told my dad that my maths teacher's a bit [pokes her tongue out, making a farting sound followed by group laughter]. He just told me to take a spoonful of cement and harden up, and I was like, eh? [Group: Yeah, hard out!] Like it's your fault and your teacher is there to teach, so listen!

Notice how vague Dave's response to his parents is. His reply of "good" could denote that he is doing well behaviourally, socially, emotionally or scholastically, or all of them. In the end, these students, just like my siblings and I, knew our reasons for not sharing these types of schooling experiences with our parents. It meant salvation from chastisement. After all, as children of the migrant dreamers, we are the privileged ones who are being educated in this country. To report mistreatment meant we were not only being disrespectful but, even worse, ungrateful. In response to Hattie's (2003) description of how Pasifika students stay on longer at school than any other ethnic group, the reason can be found in Cynthia's response: we learn to "cement" and "harden up" our minds and thereby our hearts, because family is much more important than getting an education.

\section{The world of church}

In my generation, all of the weekends were devoted to church; services were attended on the Sabbath and youth activities the other day. This was combined with twiceweekly evening prayer meetings as well as weekly choir practice. Church life, although located outside of the community within which we resided, provided my family with its social network and sense of community. 
In terms of extracurricular activities, our parents tried to ensure that these, too, were in some way connected to our church world. However, we children had opposite plans. For example, on separate occasions, our parents had paid for my older sister and me to attend piano lessons with elderly women-hers in Remuera and mine in Panmure. However, when these women passed away, so did our lessons and our parents' hope that we would one day be able to play accompaniment for the church choir. Both of us used the world of school and our commitments there as an excuse for our parents not to waste their hard-earned money on more piano lessons.

I have often reflected on why Pasifika families tend to stick to themselves and be willing to travel to the other side of the city to attend their respective village churches when there are plenty of local denominations in their own suburbs. Again, from the work of Glynn and Berryman (2005), the universal need for a sense of belonging is strong, and people congregate where they feel accepted, connected and needed. Similarly, in the classroom, children learn best when there is that sense of belonging and sense of purpose.

Likewise, the students from both schools in the current generation spoke about their family commitments to church attendance and what the world of church meant for them:

Y11 Lisa (Niuean): Church, church, all day Sunday and then every Wednesday night meetings, plus we have these occasions like conferences and all of that. Then we have family worship meetings on Sunday mornings too. Yeah, and that's just too much. Saturday's my only day off.

Y13 Dave (Samoan): I used to alternate between two churches, my mum's church, she goes to a Samoan church in Grey Lynn and my dad's church, the Catholic church just down the road there, and I work every weekend, on Saturdays and on Thursday nights. It's usually just 3 to 5 hours on Thursdays and Saturdays, like, 'cause I usually ask just for short shifts. I don't really like working longer than 5 hours.

In terms of educational outcomes for these students, schools and teachers need to be made aware of how enormous this world is for these students and how churches play a key part in the make-up of their cultural identity. For it is during the time spent in their respective churches that the home island languages are freely spoken and cultural identity knowledge is passed down to future generations.

\section{Conclusion}

Despite all that was going on within their home communities, what I found from these Pasifika students, and from my own schooling experiences, was that teachers who taught from their hearts, rather than from obligation or duty, were the ones who made a significant difference. Often these teachers were secure in their own cultural identity and willing to encourage the same from their students. These teachers became the ones students felt engaged with and hungry to learn from. It was these "responsive, readily accessible, reasonable adults" whose collective wisdom recognised and then activated "our" potential for learning. These teachers enabled the migrant dream of parents and families to come to fruition.

$$
\begin{gathered}
\text { Listen teacher } \\
\text { Listen to me } \\
\text { Don't look away } \\
\text { See my eyes they hold messages } \\
\text { that can make you understand me } \\
\text { Hold my hand and your heart } \\
\text { will warm towards me. } \\
\text { Let me dance and sing you } \\
\text { my own songs which you don't know, } \\
\text { and you might smile } \\
\text { as you've never smiled before } \\
\text { Let me tell you a story } \\
\text { of my ancient past } \\
\text { and then, maybe, you will see } \\
\text { another person in me. }
\end{gathered}
$$

Emma Kruse Va'ai

\section{References}

Anae, M. (2009). Samoans. In Te Ara-The encyclopaedia of New Zealand. Retrieved from http://www.TeAra.govt.nz/en/ Samoans

Bishop, R., \& Glynn, T. (1999). Culture counts: Changing power relations in education. Palmerston North: Dunmore Press.

Ferguson, P. B., Gorinski, R., \& Wendt Samu, T. (with Mara, D.). (2008). Literature review on the experiences of Pasifika learners in the classroom. Wellington: Ministry of Education.

Gay, G. (2000). Culturally responsive teaching: Theory, research and practice. New York: Teachers College Press.

Glynn, T., \& Berryman, M. (2005). Understanding and responding to students' behaviour difficulties. In D. Fraser, R. Moltzen, \& K. Ryba (Eds.), Learners with special needs in Aotearoa New Zealand (pp. 294-315). Palmerston North: Dunmore Press.

Hattie, J. (2003, October). Teachers make a difference: What is the research evidence? Paper presented at the Australian Council for Educational Research Annual Conference on Building Teacher Quality, Melbourne.

Hawk, K., \& Hill, J. (1998). Aiming for student achievement. set: Research Information for Teachers, 2, item 4.

Kruse Va'ai, E. (1985). Listen teacher. New Zealand School Journal. Part 4(3), 39. 
Mila, K. (2005). Dream fish floating. Wellington: Huia.

Nuthall, G. (2007). The hidden lives of learners. Wellington: NZCER Press.

Rubie-Davies, C. M., Hattie, J., \& Hamilton, R. (2006). Expecting the best for New Zealand students: Teacher expectations and academic outcomes. British Journal of Educational Psychology, 76, 429-444.

Siope, S. A. M. (2010). Children of the migrant dreamers: Comparing the experiences of Pasifika students in two secondary schools attempting to be culturally responsive to mine from a generation ago. Unpublished master's thesis, University of Waikato.

Stanley, P. (2003). Risk and resilience: Part 2, applications. Kairaranga: The Journal of New Zealand Resource Teachers of Learning and Behaviour, 4(2), 25-32.
Statistics New Zealand. (2007). Pacific profiles: 2006. Retrieved from http://www.stats.govt.nz/Census/about-2006-census/ pacific-profiles-2006.aspx

Tuala-Warren, L. (2004). A study in Ifoga: Samoa's answer to dispute healing (Te Matahauariki Institute Occasional Paper No. 4). Hamilton: University of Waikato.

\section{Notes}

1 Palagi means "of European ethnicity".

ANNIE SIOPE is a research assistant for the Te Kotahitanga project in the Faculty of Education, University of Waikato. Email: siopesamळwaikato.ac.nz

\section{NZCER Journals Online}

\section{Sign up for your free trial of our four journals now available online.}

Includes full archive of each journal, with set: Research Information for Teachers issues from 1990 onwards.

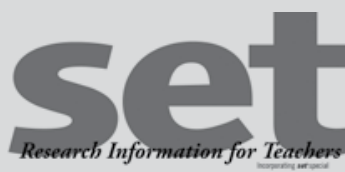

A well-established research resource for teachers

\section{ASSESSMENT MATTERS}

"Pushing" the thinking in assessment in education research, policy and practice.

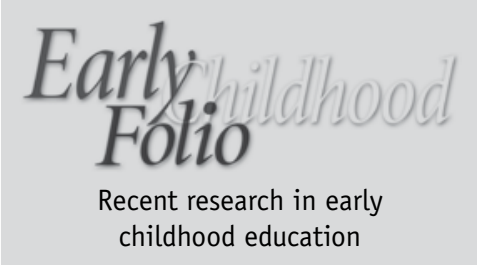

CURRICULUM MATTERS

Discussion, commentary and information about curriculum.

\section{Email subscriptions@nzcer.org.nz or call 048021386. www.nzcer.org.nz/journals}

